\title{
Erratum to: Synemin Isoforms in Astroglial and Neuronal Cells from Human Central Nervous System
}

\author{
A. Izmiryan $\cdot$ E. Peltekian $\cdot$ T. Federici $\cdot$ \\ D. Paulin - Z. L. Li Z. G. Xue
}

Published online: 24 March 2011

(C) Springer Science+Business Media, LLC 2011

Erratum to: Neurochem Res (2010) 35:881-887

DOI 10.1007/s11064-009-0111-9

The author Dr. Thais Federici is inadvertently excluded from the original publication of the article. The complete author order for the article is correctly given as:
A. Izmiryan, E. Peltekian, T. Federici, D. Paulin, Z. L. Li, Z. G. Xue.

The online version of the original article can be found under doi:10.1007/s11064-009-0111-9.

\footnotetext{
A. Izmiryan · E. Peltekian · D. Paulin · Z. L. Li

Z. G. Xue $(\square)$

Research Unit 4-Genetic and Physiopathology of Muscular

Tissue, University Pierre and Marie Curie, 7 Quai St Bernard,

75005 Paris, France

e-mail: zhigang.xue@upmc.fr

T. Federici

Department of Neurosurgery, School of Medicine,

Emory University, 101 Woodruff Circle, room 6339,

Atlanta, GA 30322, USA

e-mail: tfederi@emory.edu
} 